\title{
$\mathrm{PCB}, \mathrm{PCDD}, \mathrm{PCDF}$ 濃度の視覚的表現法の検討
}

\author{
田中 博之 \\ 独立行政法人水産総合研究センター \\ 瀬戸内海区水産研究所（ $7739-0452$ 広島県佐伯郡大野町丸石2-17-5）
}

[平成15年 6 月 26 日受理］

\section{Examination of the Visual Expressing Method of PCB, PCDD, and PCDF Concentrations}

\author{
Hiroyuki TANAKA \\ National Research Institute of Fisheries and Environment of Inland Sea \\ Fisheries Research Agency \\ (2-17-5 Maruishi, Ohno-cho, Hiroshima 739-0452)
}

[Received June 26, 2003]

\begin{abstract}
Summary
The new visual expressing methods of PCB, PCDD, and PCDF concentrations were proposed. These methods fulfill the following conditions 1) Concentration differences among isomers are clear. 2) Comparison between samples is easy. 3) Correspondence with chemical structure is easy. 4) It can be expressed compactly. These new methods were applied to the environmental samples. Considering the dynamics of PCBs and PCDD/Fs in the environment, the substitution of chlorine atoms at the $2,4,5$ positions in $\mathrm{PCB}$, and at the 6,8 and 7,8 positions in PCDD/Fs would be key chemical structures.
\end{abstract}

Key words: PCB, PCDD, PCDF, visual expressing method

\section{1.はじめに}

ポリ塩化ビフェニル (PCB) は, 酸, アルカリ, 熱に 強く, 水に難溶で油によく溶ける。また, プラスチック との親和性がよく, 接着性, 伸展性に富み電気絶縁性が 高い等, 工業用材料として優れた物質特性を持つことか ら工業製品や工業用材料として広く利用された。しか し，1966年にオジロワシ体内から PCB が検出されたの に始まり ${ }^{1}$, 外洋域や極地方の生物からも検出され, そ の環境污染が地球規模であることが明らかとなってきて いる ${ }^{2-4)}$ 。我が国に打いても1968年のカネミ油症事件発生 を受けその毒性が社会問題となり，1972年には製造中 止, 回収等の行政指導が実施された。1974年には化学物
質の審査及び製造に関する法律に基づいて第一種特定化 学物質に指定され, 製造・輸入・使用が禁止されるに 至った。1978年からは環境省による生物モニタリング調 查の一環として魚類, 貝類, 鳥類に残留する $\mathrm{PCB}$ の監視 が継続しており，2001年でそれぞれ，0.01０.40，0.02 $\sim 0.07,0.01 \sim 0.17 \mu \mathrm{g} / \mathrm{g} \cdot$ wet 濃度範囲で, 広範な地 点の試料から検出されている5。この間，1992年には 「廃棄物の処理及び清掃に関する法律」に基づく特別管 理産業廃棄物に指定され，さらに，2001年にはPCB廃棄 物の安全な処理を目的とする「ポリ塩化ビフェニル廃呆 物の適正な処理推進に関する特別措置法」(平成13年法 律第65号）が成立，7月15日に施行された。合わせて， 政令215号において施行日から15年の期間内における処 
理が定められた。

一方, 強毒性のため注目を集めるポリ塩化ジベンゾパ ラダイオキシン (PCDD), ポリ塩化ジベンゾフラン （PCDF）も，生物試料を含む多くの環境試料から検出さ れている6)。我が国においては1999年 7 月に成立したダ イオキシン類対策基本法に則り環境放出量削減のための 対策がとられている。例えば，2002年12月には污染源と して監視されている既存廃棄物焼却施設からの排ガス中 ダイオキシン濃度の基準が80ng/ $/ \mathrm{Nm}^{3} か ら ~ 1 ~ 10 n g / \mathrm{Nm}^{3}$ に強化された。

PCB や゙イオキシン類に係る一連の法的規制の実効 性を評価するために, 今後 PCB, PCDD, PCDF の環境 モニタリングの重要性は一層高まるものと考えられる が, これらの化合物には多くの異性体が存在し, 総濃度 のみでは環境での動態を把握することは難しい。例え ば，PCBには理論的に209種の異性体が存在し, 製品か らも100を超える異性体が検出され7.8), 環境残留性, 生 物蓄積性，生物影響がそれぞれ異なることが明らかにさ れている9”。同様にPCDDには75, PCDF には135の異性 体が存在しており，その環境動態の解析には主成分分析 のような統計的手法がとられている ${ }^{10.11}$ 。こういった解
析では必ずしも化学構造との関係が明確にされるわけで はなく, 複数存在する異性体の環境化学的特性と化学構 造の関係を直感的に理解できる視覚的表現法を提案する ことは, $\mathrm{PCB}, \mathrm{PCDD}, \mathrm{PCDF} の$ 環境での動態を把握す る上で有用と考えられる。

\section{2. 表現法に必要な条件}

$\mathrm{PCB}$ 等の複数存在する異性体の濃度あるいは組成を 表現するために，従来から棒グラフ ${ }^{3)}$ が用いられている。 この方法では異性体間の濃度差を示すことは可能であ り，また，複数の図を並べることで試料間の比較も可能 である。しかし，化学構造との対応が難しく，横軸には IUPAC No. あるいは体系的な略号 ${ }^{22}$ を示せる程度であ る。そして，この場合，IUPAC No. あるいは体系的な略 号毎の構造に関する知識が必要である。横軸に構造その ものを書き込むことは可能であるが，図のサイズが大き くなってしまう。この様に, 従来の棒グラフ法では, 異 性体間で濃度あるいは組成に違いがあっても，それを， 化学構造の違いや共通性の観点から理解することは難し い。新規の視覚的表現法には従来法で表現可能であった 1 ）異性体間の濃度差が明らかである。2）試料間の比

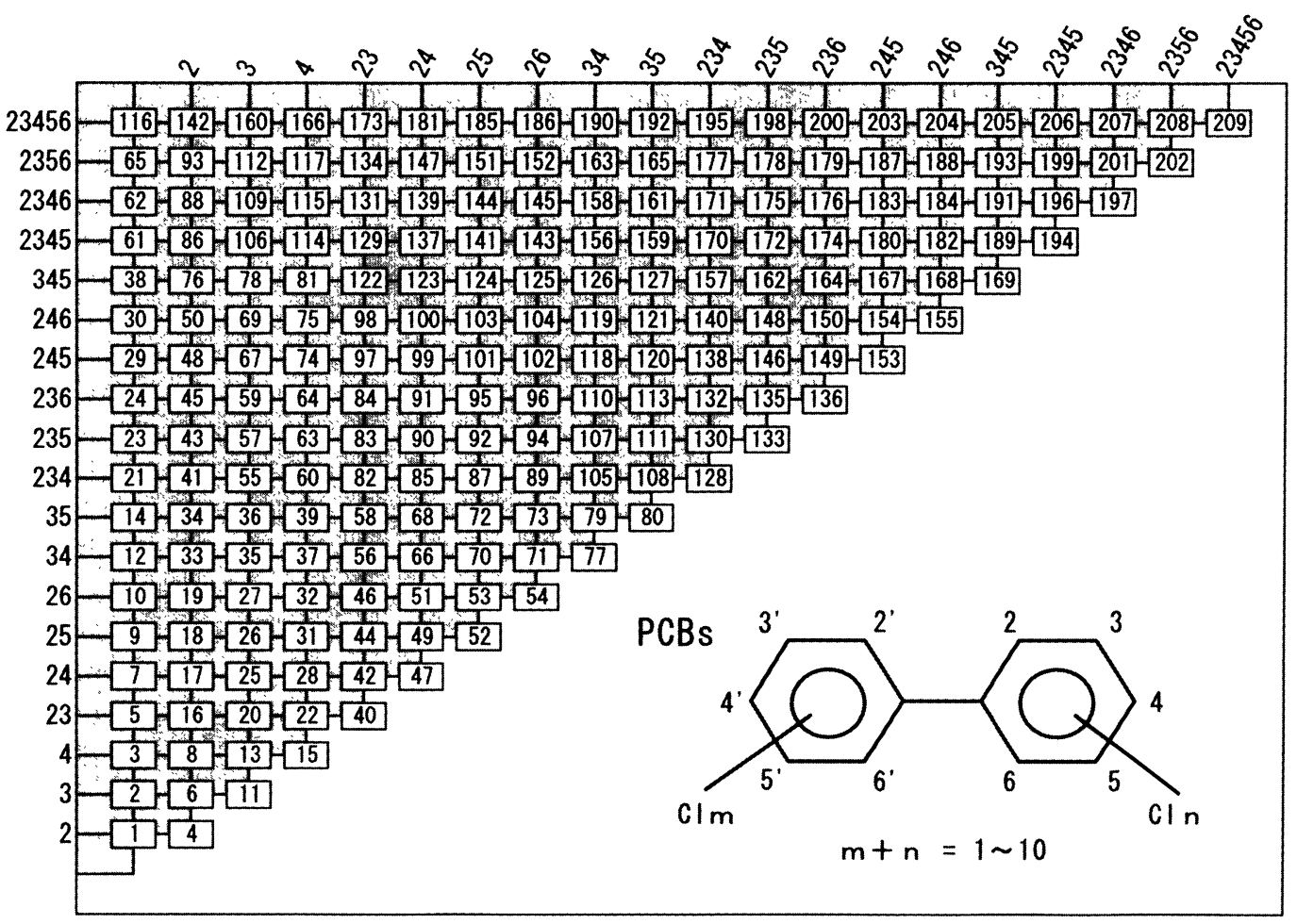

Fig. 1 IUPAC numbers and substitution patterns for $209 \mathrm{PCB}$ isomers (The digit of both axes shows the substitution position of chlorine atom) 
較が容易である。に加え，3）化学構造との対応が容易 である。そして，これらの条件を満たした上で4）コン パクトに表現できる。ことが要求される。特に3）の条 件では化学構造の共通性が容易に理解できることが重要 である。

\section{3. 新規表現法}

PCB は 2 つのベンゼン環が結合したビフェニル環の 水素が塩素に置換した化合物であり，ひとつのベンゼン 環において, 塩素の置換パターンは置換塩素なしから 5 ヶ所全てに塩素が置換したものまで20通りである。つ まり，“置換塩素なし”, “2”, “ 3 ”, “4”, “2,3”, “2, 4”, “2, 5”, “2,6”, “3,4”, “3, 5”, “2, 3, 4”, “2, 3 , 5 ”, “2, 3,6”, “2, 4, 5”, “2, 4,6”, “3, 4, 5”, “2, 3, 4, 5”, “2,3,4,6”，“2,4,5,6”，“2,3,4,5,6”で，これら20通り の塩素置換パターンから同じパターンの組み合わせを許 した上で 2 つパターンを組み合わせると 209 種類とな る $\left(20+{ }_{20} \mathrm{C}_{2}-1=209\right.$ : ただし，塩素置換なしのベンゼ ン環 2 つ組み合わせはビフェニルで PCB にはカウン トされない)。これら, 置換塩素の位置を縦軸, 横軸の それぞれにとり, それらの交点で PCB 各異性体の構造
を示すことで，全異性体を一つの図にした。図1にその 関係をIUPAC No. と共に示した。なお，PCBの体系的な ナンバリングには混乱が報告されているが13), 図 1 では PCB 製品中の各異性体濃度を測定した報告7)に従った。 そして，この図の上にClophen A30-60等量混合物の各 異性体割合 ${ }^{7}$ をの大きさの違いとして加え示したもの を図 2 に示した。この様に, 試料を示すときは交点に濃 度或いは割合を円の大きさで示すバブルグラフとするこ とで，コンパクトに示すことが可能である。さらに，バ ブルサイズを対数表示することで, 濃度レンジの広い試 料についても，低濃度の異性体間の比較が可能である。 図 2 から PCB 製品中には一方のベンゼン環の “2, 5”, “2,4,5”，“2,3,5”の位置に塩素が置換した異性体 (IUPAC No.52, 95, 101, 149, 153等) が多いことが容易に 分かる。

PCDD, PCDF についても PCB 同様の表現法を検討し た。ベンゼン環が酸素を介して結合しているので結合軸 の自由度がない, 置換できる塩素原子の数が 8 個である など, PCBの場合と異なるためコンパクトに図示するに は若干の工夫が必要であった。PCDD では塩素結合位置 1 の のベンゼン環では “1”, “2”, “1,2”, “1,3”,

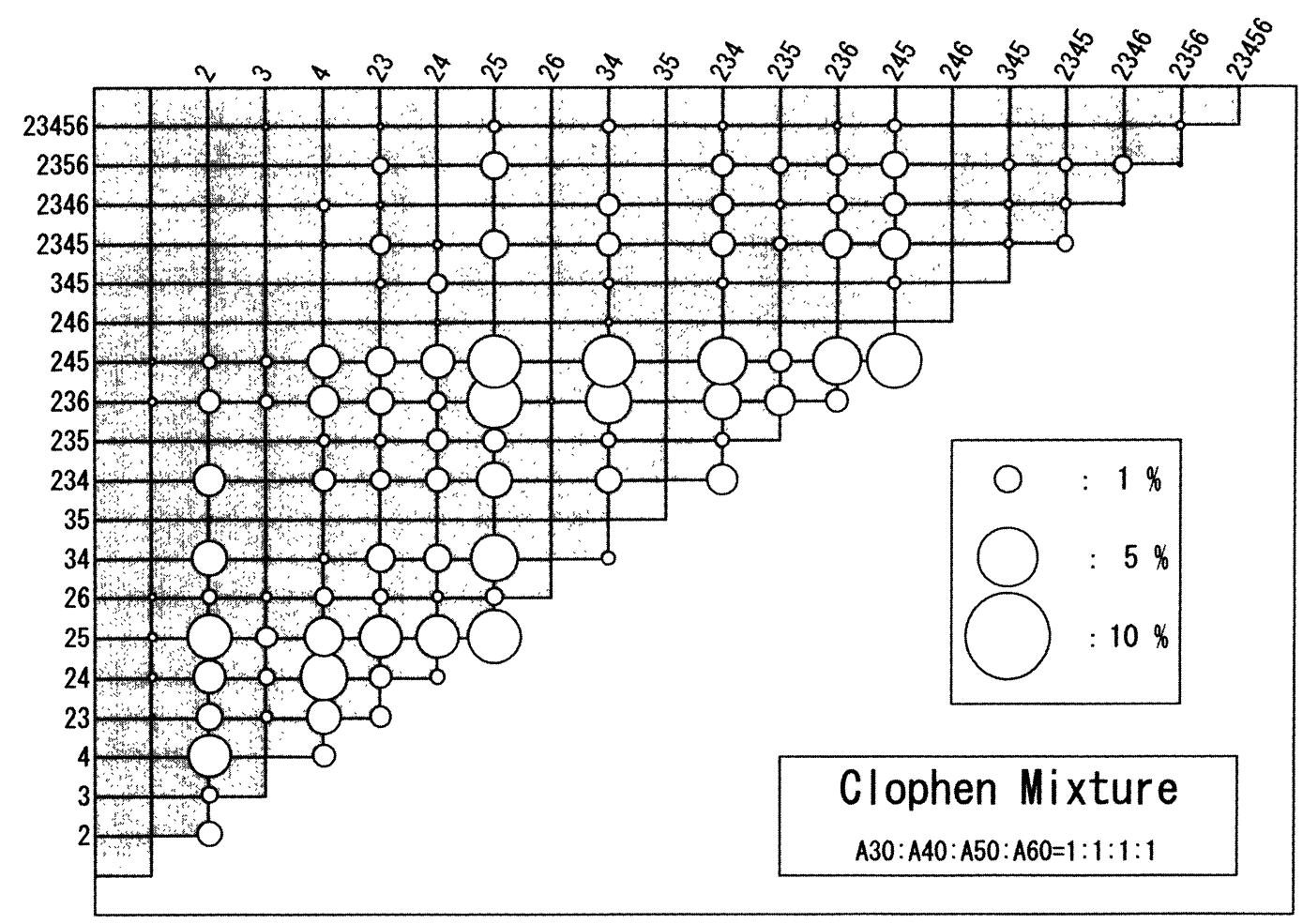

Fig. 2 Percent contribution of individual chlorobiphenyls to Clophen commercial mixture (data from ref. 7) 
“1,4”, “2,4”, “1,2,3”, “1,2,4”, “1,2,3,4”の 9 通り の塩素結合位置の組み合わせが, 塩素結合位置 6 9 9 ベンゼン環では “置換塩素なし”, “6”, “7”, “8”, “9”, “6,7”, “6,8”, “6,9”, “7,8”, “7,9”, “8,9”, “6, 7,8”, “6,7,9”, “6,8,9”, “7,8,9”, “6,7,8,9” の16通り の塩素結合位置の組み合わせがある。眓としての見易さ を考慮し, 塩素結合位置の組み合わせの少ない塩素結合 位置 1〜4のベンゼン環を縦軸に, 組み合わせの多い塩 素結合位置 6〜9のベンゼン環を横軸にとった。縦軸, 横軸の交点で示される異性体の数は, 塩素置換位置で異 なったので，それぞれの軸で異性体数の多少の順で並べ 替えた。さらに, 1,4,6- $\mathrm{T}_{3} \mathrm{CDD}$ (D23), 1,4,7- $\mathrm{T}_{3} \mathrm{CDD}$ (D24)，2,3,7-T3 $\mathrm{CDD}$ (D26) についてはベンゼン環の 結合面に垂直な軸に対して180度回転させた構造として, つまり，D23を1,6,9塩素置換として 1 と6,9の交点に, 同じく, D24を2,6,9塩素置換として 2 と6,9の交点に, D26を $2,7,8$ 塩素置換として 2 と 7,8 交点にプロットす ることで図の集積性が高まった。

一方, PCDFでは塩素結合位置 1４のベンゼン環で は “1”, “2”, “3”, “4”, “1,2”, “1,3”, “1,4”, “2, 3 ”, “2,4”, “3,4”, “1,2,3”, “1,2,4”, “1,3,4”, “2,3, $4 ”, “ 1,2,3,4 ”$ の15通りの塩素結合位置の組み合わせ
が，塩素結合位置 6 ～9 のベンゼン環では“置換塩素な L”, “6”, “7”, “8”, “9”, “6,7”, “6,8”, “6,9”, “7,8”, “7,9”, “8,9”, “6,7,8”, “6,7,9”, “6,8,9”, “7, $8,9 ”, “ 6,7,8,9 ”$ の16通りの塩素結合位置の組み合わせ がある。PCDD の表示法にあわせ, 塩素結合位置 $1 \sim 4$ のベンゼン環を縦軸に, 塩素結合位置 6 ～9 のベンゼン 環を横軸にとった。そして, 図の見易さを考慮すると PCDD 同様縦軸, 横軸それぞれ異性体数の多少の順で並 べ替える必要があった。また，1,6,7,8-T 4 CDF（F77） は鏡面対象の位置1,3,4と9 の交点にプロットすること で集積性が上がった。さらに, PCDD と PCDFで縦軸と なる塩素結合位置 1 ～致ベンゼン環の置換塩素位置を 逆にすることで，両化合物をひとつの図に示すことが可 能となった。図 3 に縦軸, 横軸の交点にそれらの構造が 示す PCDD/F の一連番号とともに示した。PCB 同様に試 料を示すときは交点に濃度或いは割合を円の大きさで示 すバブルグラフとすることで，コンパクトに示すことが 可能である。また, PCDD と PCDFで同一のバブルサイ ズが示す值を変えることで, PCDD と PCDF の濃度レン ジが異なる試料についても同時に表示可能である。

現在 PCB，PCDD，PCDF 何れに扔いても全異性体を 個別に定量することは難しい。クロマトグラム上分離が

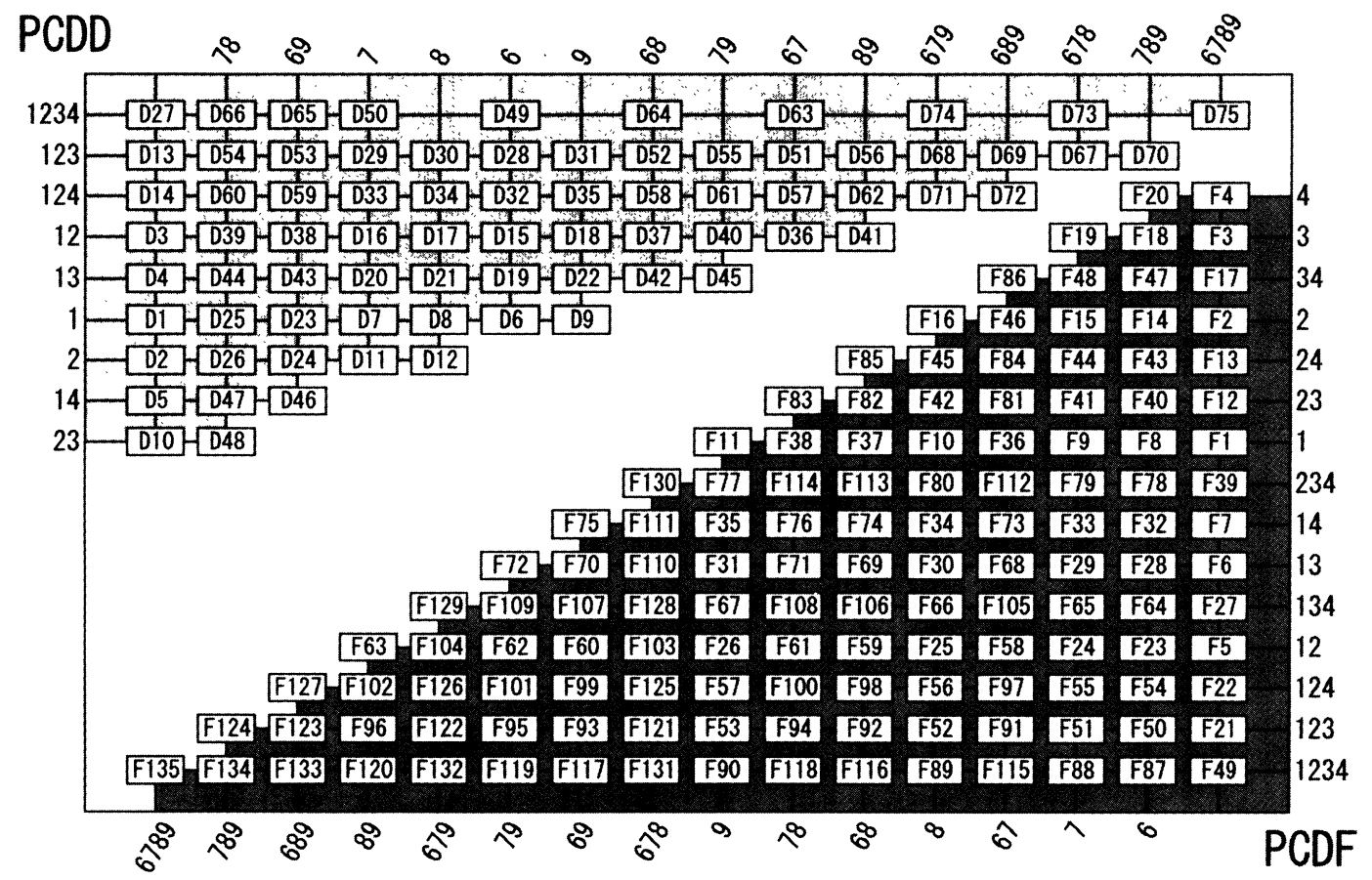

Fig. 3 Numbering and substitution pattern of PCDD/F isomers (The digit of four sides shows the substitution position of a chlorine atom) 
出来ず，ひとつのピークを複数の異性体の合量として定 量している場合は，基本的には合量值をそのピークに含 まれる異性体数で割り，それぞれを図示すべきであろ う。しかし, その構造等から存在が疑わしい異性体につ いては割愛する必要があるかもしれない。逆に，本論文 で提案している新規表現法で図示した結果，構造が類似 した個別定量可能な異性体の動態から，合量ピークの中 の主要異性体を推定できる可能性もある。

\section{4. 実試料への適応}

北西部北太平洋で採集した海鳥の一種であるエトピリ 力（Lunda cirrhata） で報告されている $\mathrm{PCB}$ 異性体濃 度 ${ }^{(4)}$ を新規表現法で図 4 に示した。IUPAC No.153, 138, 118, 99, 180等の濃度が高く，これらの異性体が一方のべ ンゼン環の2,4,5位に塩素が置換した共通の構造をもつ ことが分かる。高等生物における $\mathrm{PCB}$ の代謝では連続 した塩素未置換の領域の存在が必要で15，2,4,5位に塩 素が置換しているとそのような領域がないため残留性が 高くなると考えられる。エトピリカでは2,4,5位に塩素 が置換する異性体を合量すると全濃度の 6 割を占めた。 同様の結果は他の海鳥類でも報告されて抢り，これら 5
異性体で PCB 全体の約 7 割を占めた ${ }^{16)}$ 。さらに, 前述の 通り製品中にもこの夕イプの異性体は比較的多く, PCB の環境動態を考える上で $2,4,5$ 位塩素置換はキーとなる 構造である。また, Co-PCBの一種として毒性影響が懸 念されているIUPAC No.118 (2,3', 4, 4', 5- $\left.\mathrm{P}_{5} \mathrm{CB}\right)$ もこ のグループの 1 つであり, 生物への PCB の毒性影響を 考える上でも重要である。この様に，PCB の新規表現法 では残留性の高い異性体に共通した構造が容易に理解で きた。

図 5 に広島湾で採集した底質, 及び底質と密接に関連 し生息する甲殼類 (エビ類, カ二類)，小型底生魚類，異 体類から検出されたダイオキシン類濃度を示した ${ }^{17}$ 。何 れの試料でも PCDD と比較し PCDFで出現する異性体の 数が多い。また，凡例から分かるように異性体の濃度レ ベルは底質，甲殼類では PCDDが PCDFより高いのに対 して，魚類ではPCDD と PCDFでほぼ同レベルとなって いる。構造を見ると底質の PCDDでは，1,2,3,4位塩素 置換の異性体割合が高い，同様にPCDFにおいても $1,2,3,4$ 位塩素置換の異性体割合が高くなっている。底 質と比較し甲殼類における PCDD では 6,8 位及び相同と なる1,3あるいは7,9位塩素置換の異性体の割合が，ま

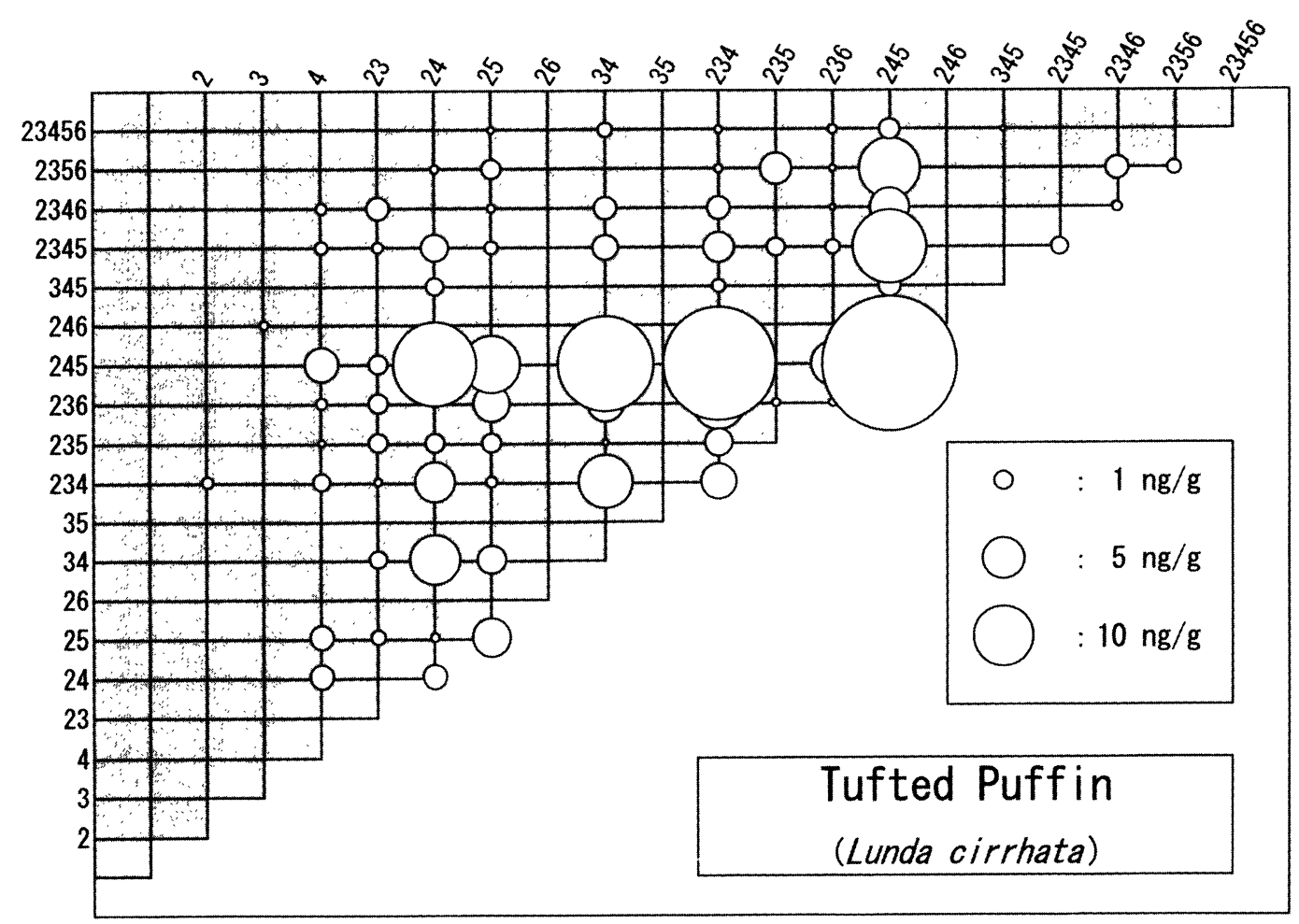

Fig. 4 Concentrations of PCB isomers in the Tufted Puffin from the northern North Pacific (data from ref. 14) 
た，PCDFでは6,8位塩素置換に加え7,8位及び相同とな る2,3位塩素置換の異性体の割合が高い。底質と比較し 魚類における PCDD では7,8位塩素置換の異性体の割合 が高くなっている。また, PCDF では検出される異性体 の数が少なく，7,8位塩素置換の異性体の割合が高い。 魚類と甲款類を比較すると, 魚類において PCDD, PCDF ともに7,8位塩素置換の異性体の割合が高い。底 質と生物を比較した場合 PCDD/F ともに，6,8位塩素置 換及び7,8位塩素置換の異性体の残留性が高いと考えら れた。この様に，新規表現法では試料間における PCDD と PCDF の濃度レベルと検出される異性体数の違いが容 易に分り，さらに，環境残留性，生物残留性の高い異性 体に共通な化学構造が理解できた。

\section{要 約}

$\mathrm{PCB}, \mathrm{PCDD}, \mathrm{PCDF}$ の異性体濃度あるいは組成につ いて, 1 ) 異性体間の濃度差が明らか, 2 ) 試料間の比較 が容易, 3 ）化学構造との対応が容易, そして, 4) コン パクトに表現できる，新規の表現法を提案した。本表現 法を環境試料に適応したところ, PCB, PCDD, PCDF の環境中での動態を考えたとき，PCBにおいては2,4,5
位の塩素置換が，PCDD/Fでは6,8位塩素置換及び7,8位 塩素置換がキーとなる構造であると考えられた。

\section{文 献}

1) Jensen, S.: Report of new chemical hazard. New Scientist 32, 612 (1966)

2) Tanabe, S., Mori, T., Tatsukawa, R. and Miyazaki, N.: Global pollution of marine mammals by PCBs, DDTs and HCHs (BHCs). Chemosphere, 12, 12691275 (1983)

3) Guruge, K.S., Tanaka, H. and Tanabe, S.: Concentration and toxic potential of polychlorinated biphenyl congeners in migratory oceanic birds from the North Pacific and Southern Ocean. $M a$ rine Environmental Research, 52, 271-288 (2001)

4) Muir, D., Riget, F., Cleemann, M., Skaare, J., Kleivane, L., Nakata, H., Dietz., R., Severinsen, T. and Tanabe, S.: Circumpolar trends of PCBs and organochlorine pesticides in the arctic marine environment inferred from levels in ringed seals. Environ. Sci. Technol., 34, 2431-2438 (2000)
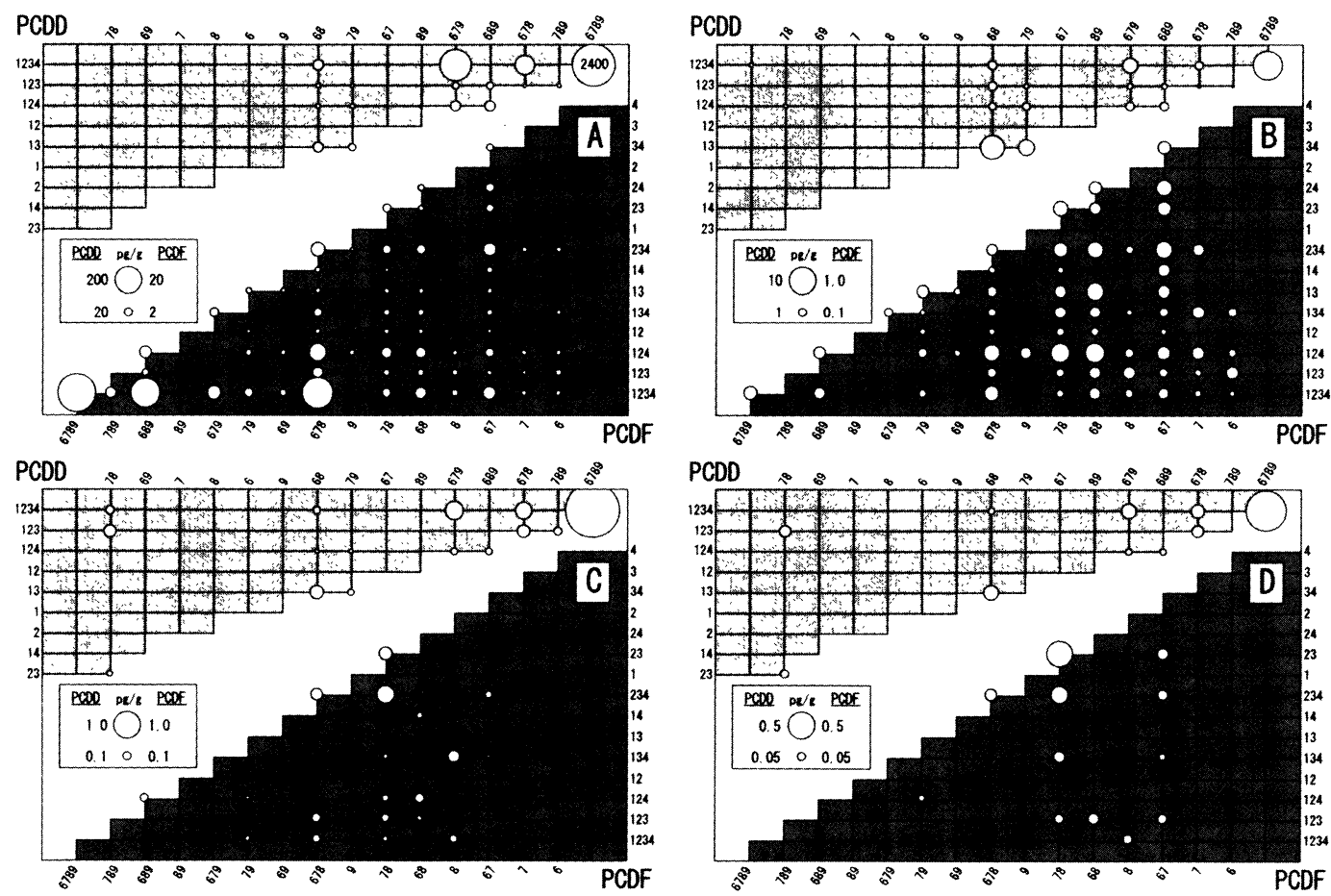

Fig. 5 Concentrations of $\mathrm{PCDD} / \mathrm{F}$ isomers in the sediment (A), crustacean (B), small benthic fish (C) and heterosomata (D) from Hiroshima Bay (data from ref. 17) 
5）環境省：化学物質と環境 (平成14年度版), pp.368 (2003)

6）佐々木裕子：ダイオキシン類による生物の污染, 環 境化学, 10, 517-532 (2000)

7) Schulz, D. E., Petrick, G., and Duinker, J. C.: Complete characterization of polychlorinated biphenyl congeners in commercial Aroclor and Clophen mixtures by multidimensional gas chromatography-electron capture detection. Environ. Sci. Technol., 23, 852-859 (1989)

8）宮田秀明, 青笹 治, 間瀬由香里, 太田壮一：キャ ピラリーカラム・ECD-ガスクロマトグラフィーに よるポリ塩化ビフェニル $(\mathrm{PCBs})$ の数值化法, 環境 化学, 4, 819-829 (1994)

9) McFarland, V. A. and Clarke, J. U.: Environmental occurrence, abundance, and potential toxicity of polychlorinated biphenyl congeners: considerations for a congener-specific analysis. Environ. Health Perspect, 81, 225-239 (1989)

10) Masunaga, S., Yao, Y., Ogura, I., Nakai, S., Kanai, Y., Yamamuro, M. and Nakanishi, J.: Identifying sources and mass balance of dioxin pollution in Lake Shinji Basin, Japan. Environ. Sci. Technol, 35, 1967-1973 (2001)

11）早川健一, 谷 治毅, 高月 紘, 酒井伸一：異性体
分布から見たポリ塩化ビフェニル (PCBs) の発生 源に関する考察一主成分分析および重回帰分析を用 いてー，環境化学，12，79-88（2002）

12) Ballschmiter, K., Buchert, H., Niemczyk, R., Munder, A. and Swerev, M.: Automobile exhausts versus municipal-waste incineration as sources of polychloro-dibenzodioxins (PCDD) and-furans (PCDF) found in the environment. Chemosphere, 15, 901915 (1986)

13) U.S.EPA: PCB ID-Theoretically consistent congener numbers.

http://www.epa.gov/toxteam/pcbid/consistent. htm

14）田中博之：エトピリカ（Lunda cirrhata）における生 態学的特性と PCBs の蓄積・代謝に関する研究, 山 階鳥類研究所研究報告, 21, 1-41（1987）

15）佐伯 茂, 田辺信介, 中川保夫, 立川 涼：フェノ バルビタールおよび3-メチルコラントレン処理 ラット肝ミクロソーム画分における PCB の組成変 化, 農化, 57, 1219-1226（1983）

16）田中博之：海鳥類における PCBs の蓄積特性と薬物 代謝能, 環境化学, 6, 559-565（1996）

17) 田中博之, 隠塚俊満, 池田久美子, 市橋秀樹, 中村 昌文, 半田洋士, 村田弘司: 広島湾の底生生物にお けるダイオキシン類の蓄積特性, pp90-91, 第12回 環境化学討論会講演要旨集 (2003) 